\title{
PROTECTIVE EFFECTS OF EXOGENOUS NITRIC OXIDE AGAINST LEAD TOXICITY IN LEMON BALM (Melissa officinalis L.)
}

\author{
JAFARNEZHAD-MOZIRAJI, Z. ${ }^{1}$ - SAEIDI-SAR, S. ${ }^{2, *}$ - DEHPOUR, A. A. ${ }^{3}$ - MASOUDIAN, N. ${ }^{1}$ \\ ${ }^{I}$ Department of Biology, Islamic Azad University, Damghan Branch, Damghan, Iran \\ ${ }^{2}$ Dr. Shariaty Technical College, Technical and Vocational University, Tehran, Iran \\ ${ }^{3}$ Department of Biology, Qaemshahr Branch, Islamic Azad University, Qaemshahr, Iran \\ *Corresponding author \\ e-mail: s_saeidisar@yahoo.com \\ (Received $6^{\text {th }}$ Jun 2017; accepted $4^{\text {th }}$ Sep 2017)
}

\begin{abstract}
This research investigated the effects of exogenous sodium nitroprusside (SNP) supplementation as nitric oxide (NO) on alleviating Pb-induced oxidative damage in lemon balm (Melissa officinalis L.) plants. $\mathrm{Pb}(100,300$ and $500 \mu \mathrm{M})$ alone and in combination with SNP $(100$ and $200 \mu \mathrm{M})$ were given to hydroponically grown Melissa officinalis L. plants. The findings suggested that in $\mathrm{Pb}-$ treated plants, height, total dry weight, and chlorophyll content of leaves markedly decreased while application of $100 \mu \mathrm{M}$ SNP alleviated the inhibitory effect of $\mathrm{Pb}$ on plant growth and chlorophyll content. $\mathrm{Pb}$ exposure caused oxidative stress by elevating lipid hydroperoxide contents of the seedlings. Application of $100 \mu \mathrm{M}$ SNP counteracted $\mathrm{Pb}$ toxicity by reducing lipid hydroperoxide contents of $\mathrm{Pb}$ treated seedlings. Furthermore, it was found that the activities of antioxidant enzymes such as polyphenol oxidase, catalase, guaiacol peroxidase, and ascorbate peroxidase were increased in $\mathrm{Pb}$-treated plants. The use of $\mathrm{NO}$ especially at low concentrations reversed $\mathrm{Pb}$-induced negative effects whereas high concentrations of $\mathrm{NO}$ had no obvious alleviating effect on $\mathrm{Pb}$ toxicity in Melissa officinalis $\mathrm{L}$. On the other hand, application of $100 \mu \mathrm{M}$ SNP could function as a defense mechanism of the plant against $\mathrm{Pb}$ toxicity and mitigate $\mathrm{Pb}$ stress.
\end{abstract}

Keywords: medicinal plant, oxidative sterss, lead pollution, antioxidant response, sodium nitroprusside

\section{Introduction}

Heavy metal pollution has become a prominent environmental problem around the world. Among heavy metals, lead $(\mathrm{Pb})$ is one of the most dangerous pollutants of the environment and $\mathrm{Pb}$ pollution in the air, water, and agricultural soil is an ecological concern due to its impact on human health and the environment. Although it is not an essential nutrient for plants, a great portion of $\mathrm{Pb}$ is easily taken up by plants from the soil and accumulated in roots while only a small fraction is translocated upward to the aerial parts of plant (Bai et al., 2015). Pb exposure affects growth and physiological parameters and leads to decreases in germination percent, length, and dry mass of roots and shoots, disturbing mineral nutrition and reducing cell division (Singh et al., 2011). In most studies, $\mathrm{Pb}$ has been known to induce oxidative stress through overproduction of reactive oxygen species (ROS) and hydrogen peroxide $\left(\mathrm{H}_{2} \mathrm{O}_{2}\right)$, which in turn act on the unsaturated lipids in the cell membranes, ultimately leading to lipid peroxidation and damages in cell membranes (Kumar et al., 2013).

Plants are exposed to a wide range of pollutants, particularly heavy metals. However, they are different in their responses to heavy metal pollution. For instance, while some are sensitive to $\mathrm{Pb}$, others show tolerance for this heavy metal and are able to take in considerable amounts of $\mathrm{Pb}$ (Nemati et al., 2013). In fact, plants have adopted 
specific ways to deal with pollution. Blocking the heavy metals' entrance into the cell via exclusion or binding them to cell wall is the first major mechanism of detoxification and this is an important mechanism for $\mathrm{Pb}$ pollution (Antosiewicz and Wierzbicka, 1999). Also, some plants have improved an anti-oxidative system, including antioxidative enzymes such as guaiacol peroxidase (GPOX), catalase (CAT), and ascorbate peroxidase (APX) (Cakmak and Horst, 1991).

Nitric oxide (NO), a free radical in living organisms, is considered a key signaling molecule and a phytohormone which has important roles in various physiological processes of plants such as germination, growth, senescence, photosynthesis, and response mechanisms to specific environmental stresses (Del Rio et al., 2004). It is reported to protect the plants against toxicity of reactive oxygen species (ROS), enhance their tolerance to abiotic stress, and improve their defense response (Besson-Bard et al., 2008; Neill et al., 2008). The application of a NO donor, SNP, confers tolerance to various abiotic stresses in plants by enhancing their antioxidant defense system under stress conditions ( $\mathrm{Xu}$ et al., 2010). Nitroprusside plays its role through the production of compounds involved in detoxification of $\mathrm{H}_{2} \mathrm{O}_{2}$ and antioxidant enzymes such as catalase (CAT), peroxidase (POD), ascorbate peroxidase (AXP), and guaiacol peroxidase (GPOX) (Tewari et al., 2006). NO has been found to reduce Pb uptake in Arabidopsis thaliana, thereby reducing toxicity symptoms (Phang et al., 2011). It also influences gene expression in response to oxidative stress in Zea mays leaves (Hermes et al., 2011). Nitroprusside decreased absorption of cadmium in Melia azedarach cuttings and improved some growth parameters under cadmium stress treatment (Arany et al., 2015). It was recently reported that exogenous application of SNP (as a NO donor) alleviated the hostile effects of abiotic stresses induced by heavy metals such as As (Hasanuzzaman and Fujita, 2013), Br and Al (Aftab et al., 2012) and Cu (Zhang et al., 2009). Pretreatment of cowpea seeds with SNP as NO donor before exposure to $\mathrm{Pb}$ had a protective effect against $\mathrm{Pb}$ toxicity conducing to an improvement of the chlorophyll value, RWC, and net photosynthetic rate by increasing antioxidant enzyme activities (Sadeghipour, 2015). Melissa officinalis L contains some phenolic and flavonoid compounds such as rosmarinic acid. Phenolic contents in plants have some antioxidant properties (Chen et al., 2001). This plant is widely used around the world because of its medicinal properties. In the Melissa officinalis L. plants treated with sodium nitroprusside, increase in concentrations of sodium nitroprusside led to an increase in oxidative stress molecules and malondialdehyde (Esmaeilzadeh et al., 2015).

Lemon balm (Melissa officinalis L.) is a member of the Lamiaceae family, which spreads widely from the western part of Europe (Ulbricht et al., 2005) to western and central parts of Iran. This plant is widely used around the world because of its medicinal properties. However, there is a paucity of data regarding the role of NO in alleviating $\mathrm{Pb}$-induced toxicity. With that background in mind, we hypothesized that $\mathrm{NO}$ may ameliorate $\mathrm{Pb}$-induced toxic effects in Melissa officinalis $\mathrm{L}$. The present work aimed at investigating the role of exogenously supplied SNP (NO donor) in alleviating Pb stress in Melissa officinalis L.

\section{Materials and Methods}

\section{Plant material and culture conditions}

Melissa Officinalis L. seeds were cultured in perlite puts 2 centimeters deep at equal distances before they were sterilized with $5 \%$ sodium hypochlorite for $15 \mathrm{~min}$ and 
washed thoroughly with distilled water. The pots were irrigated by distilled water for 10 days. After germination, the seeds were nourished with Hoagland feeding solution for 15 days. Irrigation was continued during 3-leave stage with Hoagland solutions containing different concentrations of $\mathrm{Pb}\left(\mathrm{NO}_{3}\right)_{2}(0,100,300$, and $500 \mu \mathrm{M})$ and sodium nitroprusside $(0,100$, and $200 \mu \mathrm{M})$ alone and in combination for two weeks. Our experiment was performed under regulated conditions, daily temperature of $25 / 17^{\circ} \mathrm{C}$ and $60 \pm 5 \%$ relative humidity. For the assessment of plant dry matter content, the plants were dried at $80^{\circ} \mathrm{C}$ for $48 \mathrm{~h}$, to produce a constant weight. This research was conducted under the standard conditions at Sari Agricultural Research Center in Iran.

\section{Determination of Photosynthetic pigments}

The leaves were chopped into small pieces that were extracted with $80 \%$ acetone. The absorbance was measured at $645 \mathrm{~nm}$ and $663 \mathrm{~nm}$ for chlorophyll a and b, respectively. Then photosynthetic pigments (chlorophyll a and b) were assayed as per the method of Litehtenhaler and Wellburn (1983) formulae:

$\mathrm{Chl} \mathrm{a}\left(\mathrm{mg} \mathrm{g}^{-1}\right.$ leaf fresh weight $)=[12.7($ OD663 $)-2.69($ OD645 $)] \times \mathrm{V} / 1000 \times \mathrm{W}$

Chl b $\left(\mathrm{mg} \mathrm{g}^{-1}\right.$ leaf fresh weight $)=[22.9($ OD645 $)-4.68($ OD 663) $] \times \mathrm{V} / 1000 \times \mathrm{W}$

Total Chl $\left(\mathrm{mg} \mathrm{g}^{-1}\right.$ leaf fresh weight $)=[20.2($ OD645 $)-8.02($ OD 663) $] \times \mathrm{V} / 1000 \times \mathrm{W}$

where:

$\mathrm{OD}=$ Optical Density

$\mathrm{V}=$ Volume of Sample

$\mathrm{W}=$ Weight of Sample

\section{Determination of lipid peroxidation}

Lipid peroxidation was determined by measuring MDA, a major thiobarbituric acid reactive species (TBARS), and product of lipid peroxidation (Heath and Packer, 1968). Samples $(0.2 \mathrm{~g})$ were ground in $3 \mathrm{~mL}$ of trichloroacetic acid $(0.1 \%$, w/v). The homogenate was centrifuged at $10,000 \mathrm{~g}$ for $10 \mathrm{~min}$ and $1 \mathrm{~mL}$ of the supernatant fraction was mixed with $4 \mathrm{~mL}$ of $0.5 \%$ thiobarbituric acid (TBA) in $20 \%$ trichloroacetic acid (TCA). The mixture was heated at $95^{\circ} \mathrm{C}$ for $30 \mathrm{~min}$, chilled on ice, and then centrifuged at $10,000 \mathrm{~g}$ for $5 \mathrm{~min}$. The absorbance of the supernatant was measured at $532 \mathrm{~nm}$. The value for non-specific absorption at $600 \mathrm{~nm}$ was subtracted. The amount of MDA was calculated using the extinction coefficient of $155 \mathrm{mM}^{-1} \mathrm{~cm}^{-1}$ and expressed as $\mathrm{nM} \mathrm{g}^{-1} \mathrm{FW}$.

\section{Determination of antioxidant enzymes}

For extraction of antioxidative enzymes, shoots and roots were homogenized with 50 $\mathrm{mM} \mathrm{Na} 2 \mathrm{HPO}_{4}-\mathrm{NaH}_{2} \mathrm{PO}_{4}$ buffer ( $\mathrm{pH} 7.8$ ) including $0.2 \mathrm{mM}$ ethylene diamine tetra acetic acid (EDTA) and 2\% insoluble polyvinyl pyrrolidone in a chilled pestle and mortar. The homogenate was centrifuged at 12,000 $\mathrm{g}$ for $20 \mathrm{~min}$ and the resulting supernatant was used for determining enzyme activities. The whole extraction procedure was carried out at $4{ }^{\circ} \mathrm{C}$. 
PPO activity was determined by measuring the increase in the absorbance at $420 \mathrm{~nm}$ for catechol and 4-methylcatechol substrates and at $320 \mathrm{~nm}$ for pyrogallol substrate (Dogan et al., 2007). CAT activity was measured as the decrease in the absorbance at $240 \mathrm{~nm}$ due to the decline of extinguishment of $\mathrm{H}_{2} \mathrm{O}_{2}$ by the procedure of Patra et al. (1978). APX activity was measured by the decline in the absorbance at $290 \mathrm{~nm}$, as ascorbate was oxidized (Nakano and Asada, 1981). GPX activity was calculated by using the extinction coefficient of $26.6 \mathrm{M}^{-1} \mathrm{~cm}^{-1}$ for $\mathrm{H}_{2} \mathrm{O}_{2}$ at $436 \mathrm{~nm}$ and was expressed as nKat $/ \mathrm{mg}^{-1}$ of protein. The $10 \%$ gel was stained by the procedure of Hamill and Brewbaker (1969).

\section{Statistical analysis}

All data presented here are the mean values of three independent experiments with three replicates. All results were analyzed statistically by two-way ANOVA with SAS 9.1.3 software and means were compared with the LSD test $(\mathrm{P}<0.05)$.

\section{Results}

\section{Growth, malondialdehyde content and photosynthetic pigments}

Total dry weight of $\mathrm{Pb}$-treated plant was reduced significantly compared with control (Table 1). Different concentrations of $\mathrm{Pb}(0,100,300$ and $500 \mu \mathrm{M})$ and interaction with sodium nitroprusside $(100$ and $200 \mu \mathrm{M})$ on plant growth, expressed that dry weight was increased in SNP100, however, $200 \mu \mathrm{M}$ SNP into Pb-treated solution was not diminished and dry weight of plant was decline significantly.

Effects of different concentrations of $\mathrm{Pb}(0,100,300$ and $500 \mu \mathrm{M})$ and their interaction with sodium nitroprusside $(100$ and $200 \mu \mathrm{M})$ on plant growth expressed as height are shown in Table 1. Pb exposure inhibited the growth of Melissa officinalis significantly compared with control ( $\mathrm{Pb} 0 \mathrm{Snp} 0)$; however, this inhibition was moderated by the additions of $100 \mu \mathrm{M}$ SNP. On the other hand, after application of 200 $\mu \mathrm{M}$ SNP into $\mathrm{Pb}$-treated solution, $\mathrm{Pb}$-induced inhibition on plant growth was not diminished and height of $\mathrm{Pb}$-treated plant was reduced significantly (Table 1).

According to Table 1 , the rate of MDA in shoots and roots increased in $\mathrm{Pb}$-treated plants in comparison with the control group, significantly $(\mathrm{P}<0.05)$. Increasing MDA content resulted in increased lipid peroxidation in the metal-exposed plants. Under $\mathrm{Pb}$ stress, application of low SNP concentrations (SNP $100 \mu \mathrm{M}$ ) decreased MDA content, but increasing SNP concentrations (SNP200 $\mu \mathrm{M}$ ) to $\mathrm{Pb}$ treatments did not alleviate the effects of $\mathrm{Pb}$ stress on lipid peroxidation (Table 1).

The rise in shoot chlorophyll a and b contents of Melissa officinalis plants exposed to $\mathrm{Pb}$ stress was statistically significant compared with control group; however, application of $100 \mu \mathrm{M}$ SNP alleviated $\mathrm{Pb}$ toxicity in the photosynthetic system. High concentration of SNP $(200 \mu \mathrm{M})$ had no mitigating effects on decreasing chlorophyll contents and both chlorophyll a and b contents were reduced, meaning fully compared to others (Table 1). 
Table 1. Effects of different concentrations of SNP $(0,100$ and $200 \mu M)$ on total dry weight, Chl. $a$ and b, leaf and root MDA content, leaf and root H2O2 content in Melissa officinalis under Pb stress (0, 100, 300, and $500 \mu \mathrm{M})$.

\begin{tabular}{cccccccc}
\hline Pb & SNP & $\begin{array}{c}\text { Height } \\
(\mathbf{c m})\end{array}$ & $\begin{array}{c}\text { Total dry } \\
\text { weight }(\mathbf{g})\end{array}$ & $\begin{array}{c}\text { Chl a } \\
(\mathbf{m g} / \mathbf{g ~ F W})\end{array}$ & $\begin{array}{c}\text { Chl b } \\
(\mathbf{m g} / \mathbf{g} \text { FW })\end{array}$ & $\begin{array}{c}\text { Leaf MDA } \\
\text { content } \\
\left(\mathbf{n m o l . g -}{ }^{\mathbf{1}} \text {.FW }\right)\end{array}$ & $\begin{array}{c}\text { Root MDA } \\
\text { content } \\
\text { (nmol.g- }{ }^{\mathbf{1}} \text {.FW) }\end{array}$ \\
\hline 0 & 0 & $22.85 \mathrm{a}$ & $4.6 \mathrm{~b}$ & $2.803 \mathrm{ab}$ & $0.8 \mathrm{a}$ & $26.84 \mathrm{~h}$ & $17.85 \mathrm{~h}$ \\
& 100 & $22.25 \mathrm{ab}$ & $4.843 \mathrm{a}$ & $2.853 \mathrm{a}$ & $0.801 \mathrm{a}$ & $27.4 \mathrm{gh}$ & $17.96 \mathrm{~h}$ \\
& 200 & $18.82 \mathrm{~d}$ & $4.08 \mathrm{~cd}$ & $2.61 \mathrm{bcd}$ & $0.767 \mathrm{~b}$ & $33.77 \mathrm{de}$ & $21.44 \mathrm{~g}$ \\
\multirow{2}{*}{100} & 0 & $21.58 \mathrm{bc}$ & $4.236 \mathrm{c}$ & $2.463 \mathrm{de}$ & $0.767 \mathrm{~b}$ & $35.67 \mathrm{~cd}$ & $25.43 \mathrm{f}$ \\
& 100 & $23.19 \mathrm{a}$ & $4.826 \mathrm{ab}$ & $2.706 \mathrm{abc}$ & $0.812 \mathrm{a}$ & $29.9 \mathrm{fg}$ & $21.61 \mathrm{~g}$ \\
& 200 & $18.96 \mathrm{~d}$ & $4.13 \mathrm{~cd}$ & $2.346 \mathrm{e}$ & $0.757 \mathrm{~b}$ & $37.72 \mathrm{c}$ & $26.94 \mathrm{ef}$ \\
300 & 0 & $20.64 \mathrm{c}$ & $3.903 \mathrm{de}$ & $2.053 \mathrm{f}$ & $0.66 \mathrm{~d}$ & $37.73 \mathrm{c}$ & $32.64 \mathrm{~d}$ \\
& 100 & $22.29 \mathrm{ab}$ & $4.116 \mathrm{~cd}$ & $2.496 \mathrm{cde}$ & $0.727 \mathrm{c}$ & $32.41 \mathrm{ef}$ & $28.3 \mathrm{e}$ \\
& 200 & $18.02 \mathrm{de}$ & $3.676 \mathrm{e}$ & $1.786 \mathrm{~g}$ & $0.634 \mathrm{e}$ & $38.51 \mathrm{c}$ & $34.68 \mathrm{c}$ \\
500 & 0 & $16.67 \mathrm{f}$ & $3.406 \mathrm{f}$ & $1.473 \mathrm{~h}$ & $0.502 \mathrm{~g}$ & $41.85 \mathrm{~b}$ & $37.78 \mathrm{~b}$ \\
& 100 & $17.79 \mathrm{e}$ & $3.686 \mathrm{e}$ & $2.056 \mathrm{f}$ & $0.581 \mathrm{f}$ & $37.5 \mathrm{c}$ & $32.98 \mathrm{~cd}$ \\
& 200 & $16.1 \mathrm{f}$ & $3.34 \mathrm{f}$ & $1.266 \mathrm{~h}$ & $0.453 \mathrm{~h}$ & $46.81 \mathrm{a}$ & $41.41 \mathrm{a}$ \\
\hline
\end{tabular}

Means followed by the same letter are not significantly different $(\mathrm{P}<0.05)$ according to LSD test $(n=3)$.

\section{Enzymes activity}

Under $\mathrm{Pb}$ stress condition, CAT enzyme activity in shoots and roots of Melissa officinalis increased significantly $(\mathrm{P} \leq 0.05)$. In SNP-treated plant, both concentrations of nitroprusside increased catalase activity significantly $(\mathrm{P} \leq 0.05)$ and the increase was more pronounced at SNP100 concentration. Interaction between $\mathrm{Pb}$ and SNP ed that CAT enzyme activity increased significantly in Pb+SNP100 $\mu \mathrm{M}$ but there was a significant decrease at $\mathrm{Pb}+\mathrm{SNP} 200 \mu \mathrm{M}$. It seems that low concentration of $\mathrm{NO}$ enhances negative effects of $\mathrm{Pb}$ stress (Figs. 1 and 2).

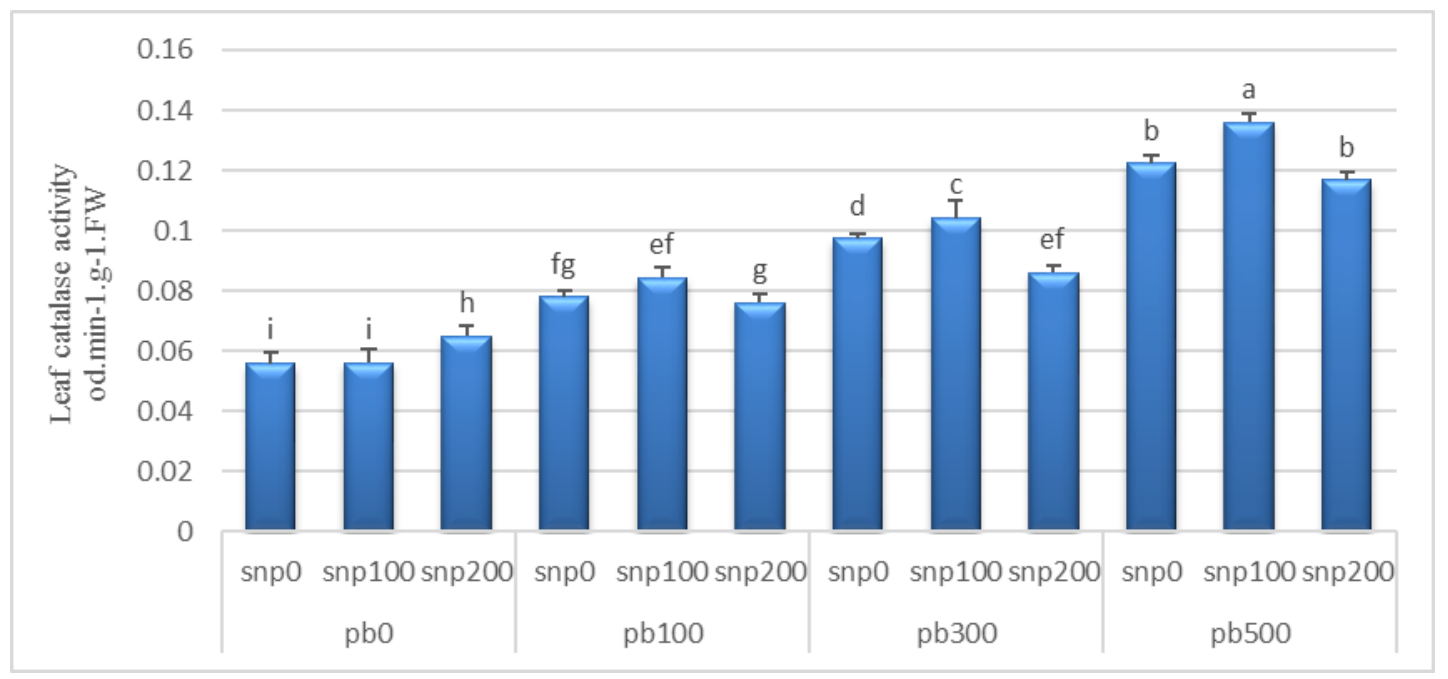

Figure 1. Effects of different concentrations of SNP on catalase activity in shoots of Melissa officinalis under Pb stress. Means followed by the same letter are not significantly different ( $P$ $<0.05)$ according to LSD test $(n=3)$. 


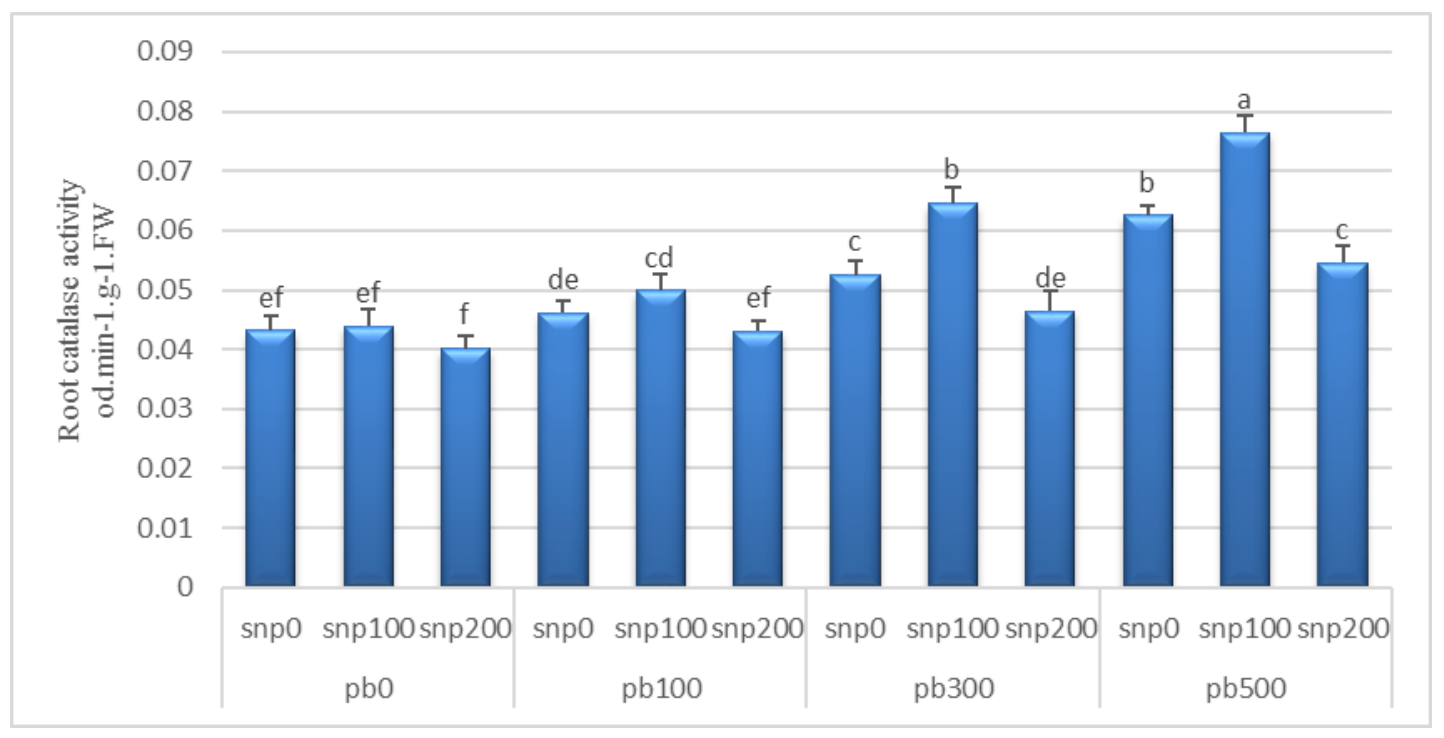

Figure 2. Effects of different concentrations of SNP on catalase activity in roots of Melissa officinalis under Pb stress $(P \leq 0.05)$. Means followed by the same letter are not significantly different $(P<0.05)$ according to LSD test $(n=3)$.

With an increase in $\mathrm{Pb}$ concentrations, leaf APX enzyme activity decreased significantly $(\mathrm{P} \leq 0.05)$. Also, with increase in SNP concentrations, APX enzyme activity decreased. Under different concentrations of $\mathrm{Pb}$ and $\mathrm{SNP}$, the maximum and minimum APX enzyme activities were recorded in $\mathrm{Pb}+\mathrm{SNP} 100$ and $\mathrm{Pb}+\mathrm{SNP} 200$, respectively (Fig. 3).

In roots, under $\mathrm{Pb}$ stress APX enzyme activity increased significantly $(\mathrm{P} \leq 0.05)$. In addition, in both roots and leaves, with increase in SNP concentrations, APX enzyme activity decreased. Also, APX enzyme activity significantly decreased $(\mathrm{P} \leq 0.05)$ in $\mathrm{Pb}+\mathrm{SNP} 200$ treatment while there was a significant increase in the activity of this enzyme in the treatment containing Pb+SNP100 (Fig. 4).

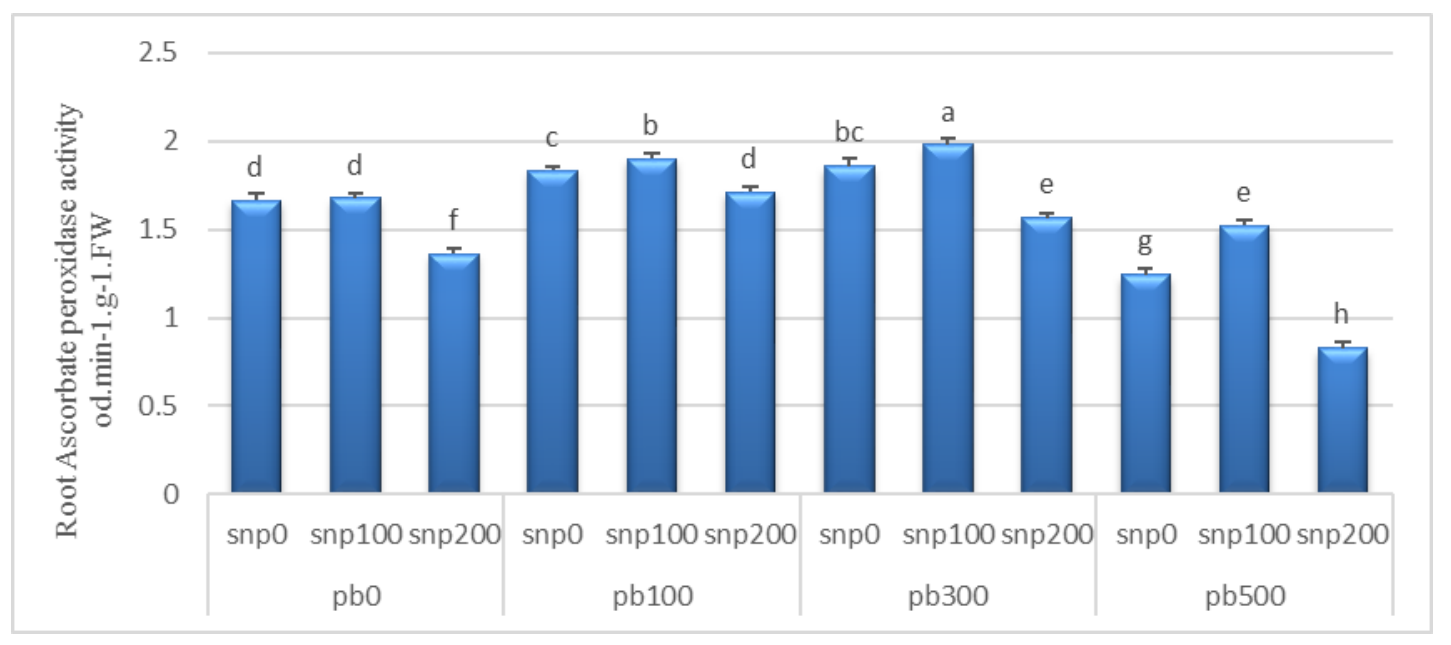

Figure 3. Effects of different concentrations of SNP on ascorbate peroxidase in roots of Melissa officinalis under Pb stress. Means followed by the same letter are not significantly different $(P$ $<0.05)$ according to LSD test $(n=3)$. 


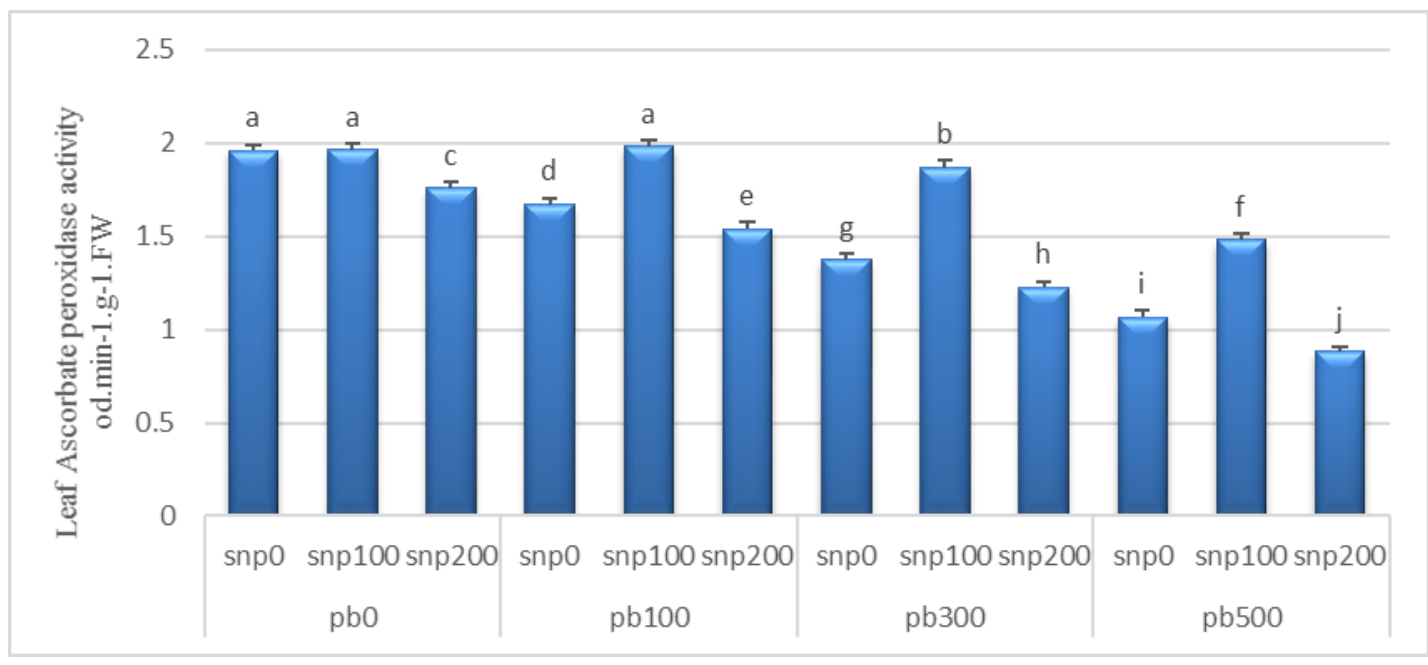

Figure 4. Effects of different concentrations of SNP on ascorbate peroxidase in shoots of Melissa officinalis under Pb stress. Means followed by the same letter are not significantly different $(P<0.05)$ according to LSD test $(n=3)$.

In leaves of Melissa officinalis under $\mathrm{Pb}$ stress, guaiacol enzyme activity did not change with an increase in lead concentration but under SNP treatment, enzyme activity decreased significantly $(\mathrm{P}<0.05)$ with increasing SNP concentrations and in fact, SNP $100 \mu \mathrm{M}$ showed the greatest increase in enzyme activity. The highest level of guaiacol activity was seen in the treatment containing $\mathrm{Pb} 300 \mu \mathrm{M}+\mathrm{SNP} 100 \mu \mathrm{M}$.

In roost, under SNP concentration, enzyme activity was unaltered with increasing SNP. Also, with increasing concentrations of lead, enzyme activity increased in roots and the increase was particularly remarkable at $\mathrm{Pb} 300 \mu \mathrm{M}$. By application of SNP to $\mathrm{Pb}$-treated plants, the highest level of guaiacol enzyme activity was seen at $\mathrm{Pb}(100 \mu \mathrm{M}$ and $300 \mu \mathrm{M})+\mathrm{SNP} 100 \mu \mathrm{M}$ while the lowest activity was seen at Pb $500 \mu \mathrm{M}+\mathrm{SNP}$ $200 \mu \mathrm{M}$ (Figs. 5 and 6$)$.

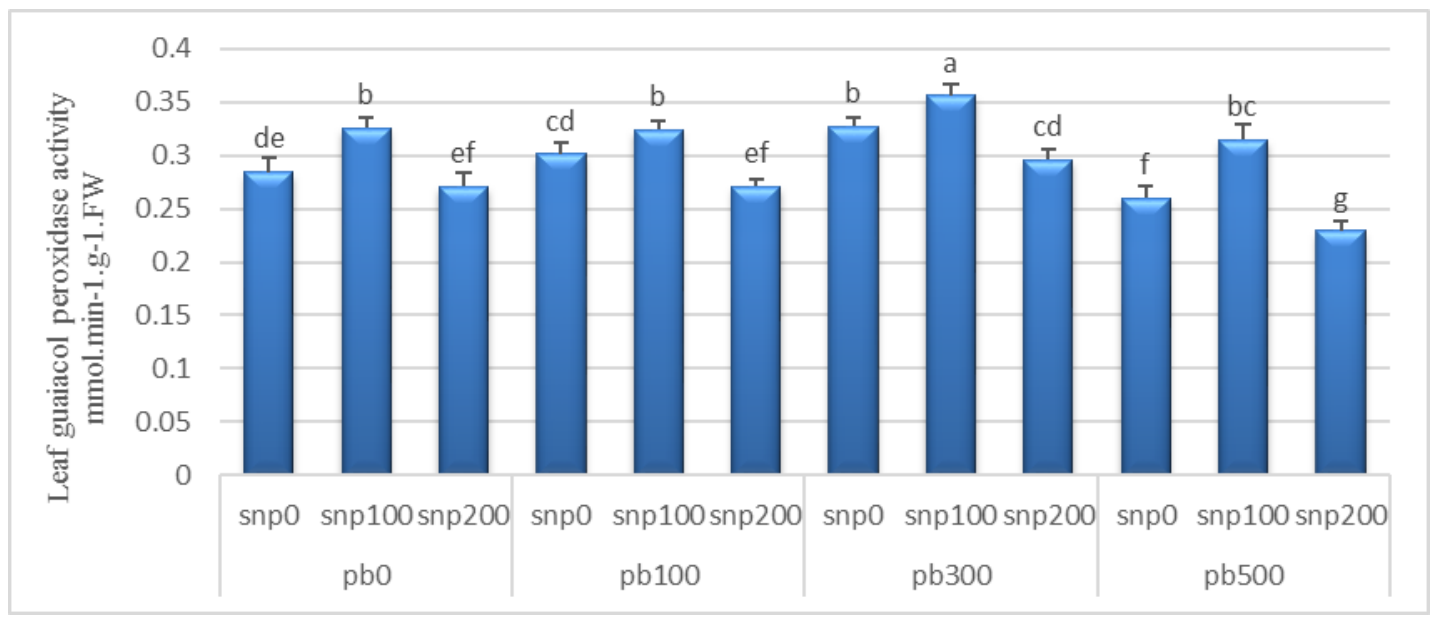

Figure 5. Effects of different concentrations of SNP on guaiacol peroxidase activity in shoot of Melissa officinalis under Pb stress. Means followed by the same letter are not significantly different $(P<0.05)$ according to LSD test $(n=3)$. 


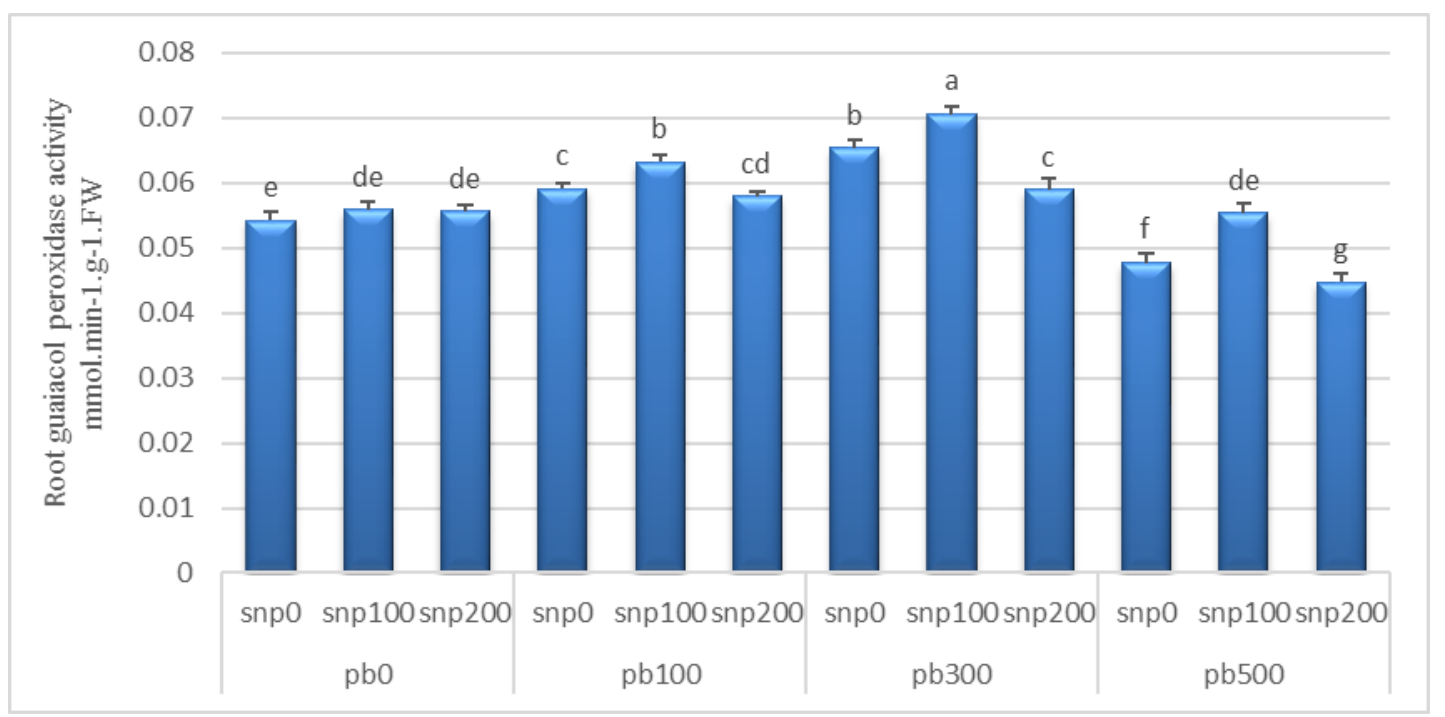

Figure 6. Effects of different concentrations of SNP on guaiacol peroxidase activity in roots of Melissa officinalis under Pb stress. Means followed by the same letter are not significantly different $(P<0.05)$ according to LSD test $(n=3)$.

In leaves and roots of Melissa officinalis under $\mathrm{Pb}$ stress, polyphenol oxidase activity increase with increasing lead concentration except in $\mathrm{Pb} 500 \mu \mathrm{M}$. Under SNP concentrations, enzyme activity increased significantly $(\mathrm{P} \leq 0.05)$ with increasing SNP and SNP $100 \mu \mathrm{M}$ showed the greatest increase in polyphenol oxidase activity. The highest level of polyphenol oxidase activity was seen at $\mathrm{Pb}(100 \mu \mathrm{M}$ and $300 \mu \mathrm{M})+$ SNP $100 \mu \mathrm{M}$. Under SNP treatment, the highest level of polyphenol oxidase activity was seen at $\mathrm{Pb}(100 \mu \mathrm{M}$ and $300 \mu \mathrm{M})+\mathrm{SNP} 100 \mu \mathrm{M}$ and the lowest level of activity was seen at Pb $500 \mu \mathrm{M}+\mathrm{SNP} 200 \mu \mathrm{M}$ (Figs. 7 and 8).

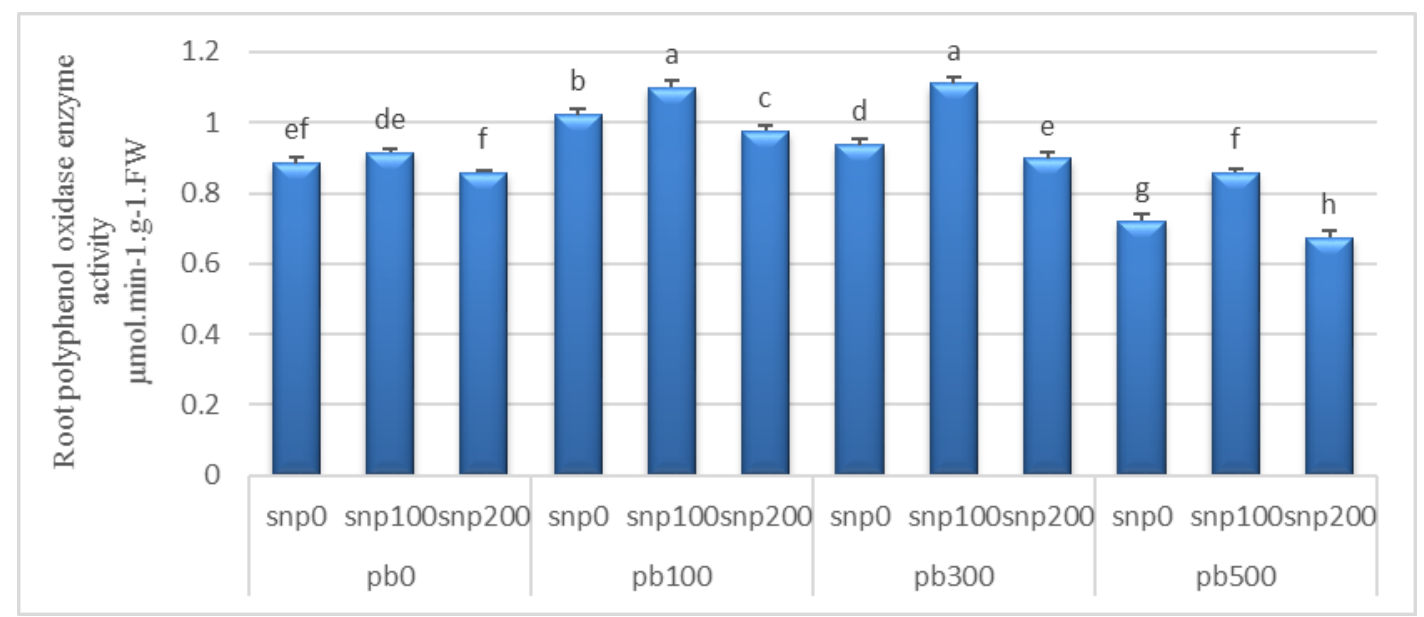

Figure 7. Effects of different concentrations of SNP on polyphenol oxidase activity in roots of Melissa officinalis under Pb stress. Means followed by the same letter are not significantly different $(P<0.05)$ according to LSD test $(n=3)$. 


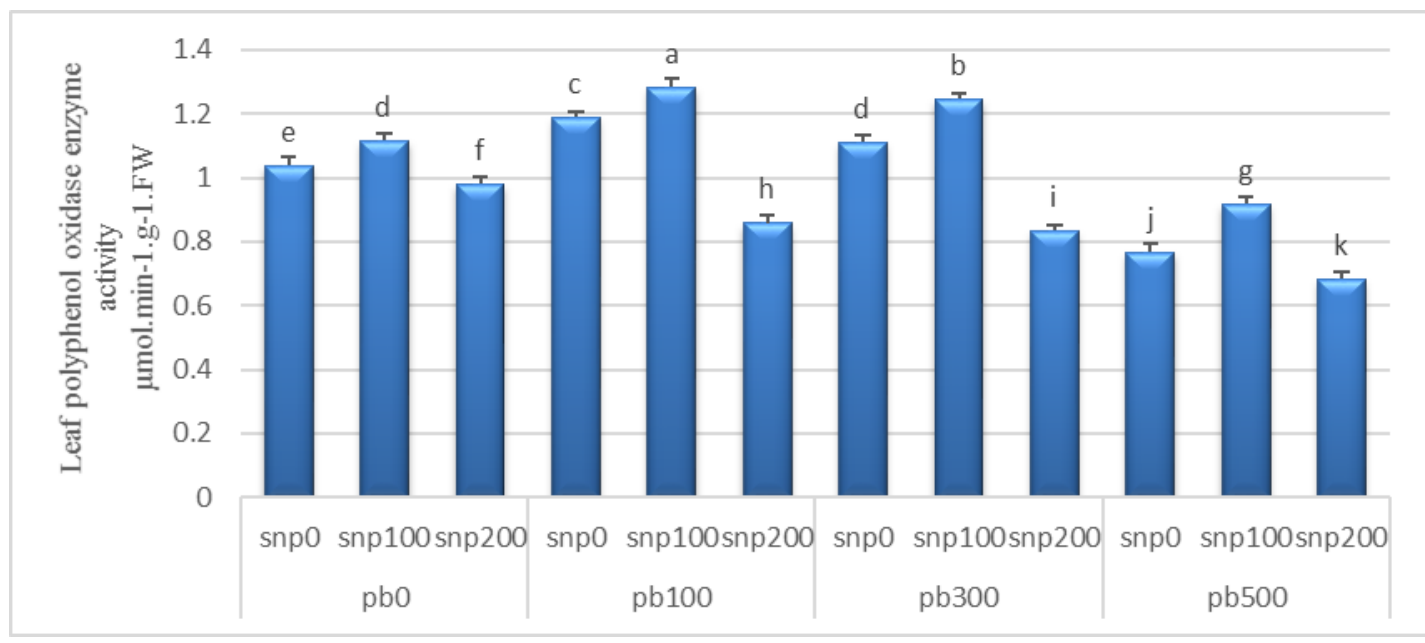

Figure 8. Effects of different concentrations of SNP on polyphenol oxidase activity in shoots of Melissa officinalis under Pb stress. Means followed by the same letter are not significantly different $(P<0.05)$ according to LSD test $(n=3)$.

\section{Discussion}

$\mathrm{Pb}$ is a toxic heavy metal that exerts adverse effects on morphology and growth of plants causing inhibition of enzyme activities. It has been suggested that exogenous application of the NO donor, sodium nitroprusside (SNP), enhances plant tolerance to heavy metals (Kumari et al., 2010) and oxidative stress (Esim and Atici, 2013). In the present study, the probable effects of exogenous NO was investigated on reducing lead toxicity in Melissa officinalis. Different concentrations of $\mathrm{NO}$ were applied in the $\mathrm{Pb}$ treated plants and the physiological parameters of Melissa officinalis under Pb Stress were investigated under different $\mathrm{NO}$ concentrations.

Plant biomass is a good indicator for characterizing the growth performance of plants in the presence of heavy metals. Results indicated that application of $\mathrm{Pb}(100,300$, and $500 \mu \mathrm{M}$ ) especially concentration of $500 \mu \mathrm{M}$ decreased the dry weight of Melissa officinalis. However, simultaneous application of low concentration of NO (100 $\mu \mathrm{M})$ increased the dry weight and height of Melissa officinalis. Pb-induced growth inhibition in this study was reflected by total dry weight. Similar response to lead treatment was previously reported in various plants (Brunet et al., 2009). Decrease in growth parameters (dry weight and height) in Melissa officinalis plants might be the result of changes in metabolic processes, e.g. oxidative damage, nutrient uptake, and photosynthesis or it might be associated with the inhibition of mitotic index observed under Pb heavy metal treatment (Sheldon and Menzies, 2005). Previous studies on the mechanism of $\mathrm{Pb}$ toxicity suggested that $\mathrm{Pb}$ binds to nucleic acids and causes aggregation and condensation of chromatin, inhibiting the process of replication and transcription and ultimately affecting cell division and plant growth (Johnson, 1998). In our study, $\mathrm{Pb}$-induced inhibition was significantly reduced by the lower concentration of NO. The mitigation effect of lower concentration of NO might be because NO improved photosynthesis by increasing chlorophyll content and counteracted oxidative damage by decreasing the generation of ROS. When the higher NO concentration was applied in Melissa officinalis plants, the mitigation effect was not obvious.

In the present study, the chlorophyll content significantly decreased with the increasing concentrations of externally supplied $\mathrm{Pb}$ in Melissa officinalis. This reduction 
in chlorophyll content can be regarded as a specific response of the plants to metal stress, which resulted in chlorophyll degradation and inhibition of photosynthesis (Gajewska et al., 2006). Chlorophyll content showed maximum range at $\mathrm{Pb}(100 \mu \mathrm{M})$ and it was decreased beyond that concentration. Heavy metals inhibit chlorophyll and other pigments biosynthesis. Lead may impair the uptake of essential elements, such as $\mathrm{Mg}$ and $\mathrm{Fe}$, for chlorophyll biosynthesis, substitute divalent cations, prevent enzyme activity like aminolevulinic acid dehydratase and increase chlorophyll biodegradation by enhancing chlorophyllase activity (Nareshkumar et al., 2014; John et al., 2009; Prasad and Prasad, 1987). Therefore, reducing the amount of chlorophyll can be due to several factors, namely, inhibition of enzymes associated with chlorophyll biosynthesis (John et al., 2009), inhibition of Calvin cycle enzyme activity (Sharma and Dubey, 2005), obstruction of electron transportation (Pourrut et al., 2011), and stomatal closure and distortion of chloroplast ultrastructure (Bharwana et al., 2014; Bai et al., 2015). Also, it may be the result of interaction of $\mathrm{Pb}$ with $\mathrm{SH}$ group of enzymes of chlorophyll biosynthesis as well as lipid peroxidation-mediated degradation as indicated by Singh et al. (2006). Similar cause was suggested by Tanyolac et al. (2007) in maize (Zea mays L.) under $\mathrm{Cu}$ stress.

Similarly, reduction in the chlorophyll content has been reported in many plant species exposed to $\mathrm{Pb}$ (Bharwana et al., 2014; Malar et al., 2014). Our results indicated that NO-mediated improvement of chlorophyll contents played a role in the enhancement of photosynthesis. In this experiment, exogenous $\mathrm{NO}$ at lower concentration $(100 \mu \mathrm{M})$ increased the chlorophyll content under $\mathrm{Pb}$ toxicity but high concentration $(200 \mu \mathrm{M})$ of $\mathrm{NO}$ had no positive effect and chlorophyll content significantly decreased at $\mathrm{Pb}(500 \mu \mathrm{M})(\mathrm{P}<0.05)$. A high NO-induced accumulation of chlorophyll was also observed under Cd stress in Rapeseed and tomato (Jhanji et al., 2012) and wheat under As-induced oxidative stress (Hasanuzzaman and Fujita, 2013).

It was found that NO raised the antioxidant enzyme activity and consequently reduced chlorophyll desolation induced by ROS. On the other hand, NO also protected chlorophyll by increasing the uptake of $\mathrm{Fe}$ and $\mathrm{Mg}$ under Pb stress (Bai et al., 2015). In this way, NO protects chlorophyll by improving its biosynthesis and reducing its destruction under $\mathrm{Pb}$ stress conditions.

In our study, the MDA level was significantly increased by $\mathrm{Pb}$ treatment. Increase in the concentration of lead was observed to increase the level of malondialdehyde production. MDA is the final product of peroxidation of membrane lipids and accumulates when the plants are subjected to oxidative stress. Therefore, MDA level is routinely used as an index of lipid peroxidation under stress conditions. A high level of MDA is demonstrative of an increased formation of ROS and oxidative damage. Actually, ROS reject hydrogen from unsaturated fatty acids and produce lipid radicals and reactive aldehydes, which deform the lipid bilayer (Kumar et al., 2013). Pb is known to induce oxidative stress in plants due to the elevated manufacture of ROS (Singh et al., 2011). In this work, increasing MDA levels showed that oxidative stress and lipid peroxidation of membranes were induced by $\mathrm{Pb}$ stress in Melissa officinalis plants. This is supported by many studies, e.g., $\mathrm{Pb}$ toxicity caused oxidative damage and elevated MDA content in mung bean (Hassan and Mansoor, 2014), elsholtzia argyi (Islam et al., 2007), and cotton (Bharwana et al., 2014).

It was also observed in the present study that application of SNP $100 \mu \mathrm{M}$ under $\mathrm{Pb}$ stress conditions inverted the $\mathrm{Pb}$ toxicity effect and decreased the MDA content compared to $\mathrm{Pb}$ treatment alone. However, the use of high concentrations of NO did not 
mitigate the oxidative effects of lead. NO moderated $\mathrm{Pb}$ stress in Melissa officinalis plants by averting oxidative damage via the enhancement of antioxidant enzyme activity. This suggests that NO acts as an efficient ROS scavenger and/or membrane stabilizer in Melissa officinalis plants subjected to Pb stress. The reaction of $\mathrm{NO}$ with ROS could prevent the damage to the membranes. It has been demonstrated that the reaction of NO with lipid alcoxyl (LO) and peroxyl (LOO-) radicals is quick (Beligni and Lamattina, 1999). Nitric oxide has also been reported to inhibit ion drip from plant tissue and protect plants against membrane damage due to lipid peroxidation under various stress conditions. This role of NO has been observed in heavy metal stress induced by Cd (Kumari et al., 2010), Br (Esim and Atici, 2013), and Al (Wang and Yang, 2005).

Under normal conditions, ROS are produced at a low concentration and there is a balance between the generation and alleviation of ROS. This balance may be disturbed by many environmental stresses. In order to protect themselves against oxidative stress, plants have developed a compound antioxidative protection system for scavenging ROS (Sharma et al., 2012). In order to scavenge ROS and to escape oxidative injury, plants possess an antioxidative system including antioxidative enzymes. Antioxidant system plays an important role in the plants' tolerance to stress conditions, which is based on the fact that the activity of one or more of these enzymes or antioxidant substances in general increases in plants exposed to stressful condition and this enhancement is related to increased stress tolerance (Fecht-Christoffers et al., 2003) and is considered as an efficient system for detoxification and cleaning up of the toxic oxygen species through an adaptive mechanism involving upregulation of anti-oxidative enzymes like SOD, CAT, PPO, APX, and GPX (Foyer et al., 1994).

Our results show that activities of enzymes had various effects on Melissa officinalis under $\mathrm{Pb}$-stress. APX enzyme activity decreased with increasing $\mathrm{Pb}$ concentrations but CAT and PPO enzyme activities increased while GPX enzyme activity was unchanged compared to the controls. However, application of exogenous NO, particularly $100 \mu \mathrm{M}$ improved antioxidant enzyme activity. Modification in the activity of antioxidative enzymes with $\mathrm{Cd}$ stress has been reported by a number of researchers (Mishra et al., 2008; Laspina et al., 2005).

Our results show that the maximum activity of CAT was found at $\mathrm{Pb} 500 \mu \mathrm{M}$ and we found that with increasing concentration of the lead, activity of CAT increased. CAT is a generally present oxidoreductase that disintegrates $\mathrm{H}_{2} \mathrm{O}_{2}$ to water and molecular oxygen, and it is one of the key enzymes involved in the ejection of toxic peroxides. Increase in CAT activity can be illustrated by an increase in its substrate, to support the level of $\mathrm{H}_{2} \mathrm{O}_{2}$ as an adaptive mechanism of the plants (Reddy et al., 2005). Therefore, reduction in the activities of CAT might be due to the formation of a protein complex with metals that results in the structural integrity of proteins (Mohan et al., 1997). At higher concentration of $\mathrm{Pb}$ the activity of protein-based enzyme might be reduced due to the effect of ROS through reduced enzyme synthesis or change in assembly of its subunits (Verma and Dubey, 2003). CAT enzyme can play a role in controlling $\mathrm{H}_{2} \mathrm{O}_{2}$ level in cells. In subcellular compartments of pea root cells increased catalase activity was observed when plants were grown in nutrient $\mathrm{Pb}\left(\mathrm{NO}_{3}\right)_{2}$. However, a decline in the activity of catalase with an increased heavy metal concentration has also been observed in Lemna gibba (Parlak and Yilmaz, 2013) and in Becopa monnera (Mishra et al., 2006). Laspina et al. (2005) reported a decline in CAT activity under Cd stress. Thus, it 
seems that the differences in activities of antioxidant enzymes in heavy metal treated plants are highly dependent on species and experimental model.

Our results indicate an enhancement in the activity of GPX and PPO by the low concentration of $\mathrm{Pb}$, suggesting that this enzymes work as an essential defense tool to resist $\mathrm{Pb}$-induced oxidative damage in plants. GPX is located in cytosol, cell wall, vacuole, and in extracellular spaces. Increased peroxidase activity in $\mathrm{Pb}$-stressed plants might be possibly due to increased release of peroxidases localized in the cell walls. Under sub lethal salinity and metal toxicity conditions, level of peroxidase activity has been used as potential biomarker to evaluate the intensity of stress. Similar to our findings, the activity of guaiacol peroxidase (GPX) increased in S. Roxburghiana plants exposed to $\mathrm{Pb}$ and in Lemna minor (Paczkowsk et al., 2007).

In the present study, APX activity was different in shoots and roots of Melissa officinalis under $\mathrm{Pb}$ stress. It was enhanced at low concentration of $\mathrm{pb}$ in roots, but, decreased in shoots. APX is generally attributed to an adaptive mechanism against increase levels of ROS content produced by $\mathrm{Pb}$ metal ions. Enzymes of ascorbate are localized mainly in chloroplasts and in other cellular organelles and cytoplasm, where they play an important role in combating oxidative stress. The positive correlation between APX activity and excess ROS may be attributed to effective scavenging of $\mathrm{H}_{2} \mathrm{O}_{2}$ content to protect stressed plants against oxidative damage induced under lead stress. Similar to the results observed in the present study, an increase in APX activity in plants following exposure of heavy metals was reported by Malar et al. (2014) in water hyacinth. In Phaseolusvulgaris and Pisumsativum (Rodriguuez-Serrano et al. 2006) and Ceratophyllum demersum (Mishra et al., 2008) APX reduced under Cd stress, but a decline in APX activity under Cd stress was reported by Gomes-Júnior et al. (2006).

Our results showed that Polyphenol Oxidase activity increased by the low concentration of $\mathrm{Pb}$. Similar our study, Chinmayee et al. (2014) demonstrated that, PPO activity in Jatropha curcas L. increased in all plant parts under chromium, cadmium and lead stress. Also, Saffar et al. (2009) reported that in Arabidopsis thaliana, PPO activity might be the result of extended heavy metal stress. PPO catalyzes the formation of highly active Quinone that reacts with amino or sulfhydryl groups in proteins or enzymes. As a result, these reactions lead to changes in physical, chemical, or nutritional characteristics of proteins and, in many cases, to inactivation of enzymes including PPO (Mayer and Harel, 1979).

All the antioxidant enzymes studied in this work had maximum activity in shoots compared to roots. This might be due to moving of $\mathrm{Pb}$ in all parts as a micronutrient and this enhances the concentration of antioxidant enzymes in shoots compared to roots. In our study SNP $(100 \mu \mathrm{M})$ was effective in improving all measured traits in the plants under lead stress but it had no positive effect in high concentration of $\mathrm{Pb}$ and this might be due to the fact that NO is itself a ROS and its dual behavior (protective or toxic) depends on the conditions (Beligni and Lamattina, 1999). The protective role is based on its capacity to regulate the level and toxicity of ROS. In many studies, the alleviation of oxidative damage by NO was attributed to the induction of activity of various ROSscavenging enzymes (Esim and Atici, 2013). The present observation is in agreement with the previous findings on rice roots treated with As (Rodríguez-Serrano et al., 2006), and Cassia tora roots treated with $\mathrm{Al}$ (Kumari et al., 2010).

Two mechanisms have been reported which may explain NO protective action against oxidative damage. One possibility is that NO might activate antioxidant systems 
to scavenge ROS. Beside the role of NO in the activation of antioxidant enzymes that scavenge ROS, it can also react with $\mathrm{O}_{2}{ }^{-}$and generate peroxynitrite $\left(\mathrm{ONOO}^{-}\right)$. $\mathrm{ONOO}^{-}$ is unstable and may be protonated and disintegrated to a nitrate anion and a proton, or it can react with $\mathrm{H}_{2} \mathrm{O}_{2}$ to produce a nitrite anion and oxygen (Fan et al., 2014). Second, it is now accepted that NO acts as a second messenger in plants. The cytoprotective role of NO is mainly based on its ability to maintain the cellular redox homeostasis and to regulate the level and toxicity of ROS (Hayat et al., 2010). Present results indicate that SNP plays a protective role in APX, PPO, CAT, and GPX activity in Melissa officinalis. In the present study, the application of high concentration of NO did not reduce $\mathrm{Pb}$ induced ROS damage. In fact it even produced more toxic effects in Melissa officinalis. One of the most intriguing behaviors in NO biology is its dual function as a potent oxidant and effective antioxidant. This dual role of NO might depend on its concentration as well as on the environmental conditions.

\section{Conclusion}

The present study demonstrated that $\mathrm{Pb}$ stress caused oxidative damage and membrane lipid peroxidation, leading to a significant decrease in chlorophyll content and shoot and root growth in Melissa officinalis plants. On the other hand, application of SNP as NO donor in Melissa officinalis under Pb stress had a protective effect against $\mathrm{Pb}$ toxicity by increasing antioxidant enzyme (PPO, CAT, APX, and GPX) activities leading to an improvement of the chlorophyll content and dry weight. Thus, exogenous $\mathrm{NO}$ can be used to alleviate $\mathrm{Pb}$ toxicity in Melissa. In fact, the lower concentration of $\mathrm{NO}(100 \mu \mathrm{M})$ had a higher protective effect on $\mathrm{Pb}$ toxicity, while high concentration of NO $(200 \mu \mathrm{M})$ did not alleviate $\mathrm{Pb}$ toxicity considerably. NO may help plants to survive stressful conditions through its function as a signaling molecule in the activation of antioxidative enzymes or its direct reaction with active oxygen, nitrogen, and lipid radicals. While supplementation of SNP resulted in growth enhancement, as well as increase in the contents and activities of all investigated biochemical components. Thus, our results indicate that SNP application might alleviate $\mathrm{Pb}$ toxicities and regulate plant growth and development of Melissa officinalis and that $\mathrm{Pb}$ tolerance of Melissa officinalis cultivated in $\mathrm{Pb}$-mediated nutrient solution increased at low concentrations of NO. This indicates that NO acts as an efficient ROS scavenger and membrane stabilizer in Melissa officinalis plants exposed to $\mathrm{Pb}$ stress.

\section{REFERENCES}

[1] Aftab, T., Khan, M. M., Naeem, M., Idrees, M., Moinuddin, Teixeira da Silva, J.A, Ramd M. (2012): Exogenous nitric oxidedonor protects Artemisia annua from oxidative stress generatedby boron and aluminium toxicity. - Ecotoxicology and environmental safety 80 : 60-68.

[2] Antosiewicz, D., Wierzbicka, M . (1999): Localization of lead in Allium cepa L., cell by electron microscopy. - Journal of microscopy 195: 139-146

[3] Arany, A. M, Mirzaee, N., Sovdaeizadeh, H., Mirshamsi, H. (2015): The effect of cadmium and sodium nitroprusside (SNP) on growth and some physiological parameters on Melia azedarach. - journal of plant process and function 4(11): 127-136.

[4] Bai, X.Y., Dong, Y.J., Wang, Q. H., Xu, L. L., Kong, J., Liu, S. (2015): Effects of lead and nitric oxide on photosynthesis, antioxidative ability and mineral element content of perennial rye grass. - Biologia plantarum 59(1): 163-170. 
[5] Beligni, M. V., Lamattina, L. (1999): Is nitric oxide toxic or protective? - Trends in plant science 4: 299-300

[6] Besson-Bard, A., Pugin A. and Wendehenne, D. (2008): New insights into nitric oxide signaling in plants. - Annual Review of Plant Biology 59: 21-39

[7] Bharwana, S. A., Ali, S., Farooq, M. A., Ali, B., Iqbal, N., Abbas, F. (2014): Hydrogen sulfide ameliorates lead-induced morphological, photosynthetic, oxidative damages and biochemical changes in cotton. - Environmental science and pollution research international 21(1): 717-731.

[8] Brunet, J., Varrault, G., Zuily-Fodil, Y., Repellin, A. (2009): Accumulation of lead in the roots of grass pea (Lathyrus sativus L.) plants triggers systemic variation in gene expression in the shoots. - Chemosphere 77(8):1113-1120

[9] Cakmak, I., Horst, W. J. (1991): Effect of aluminium on lipid peroxidation, superoxide dismutase, catalase and peroxidase activities in root tips of soybean (Glycine max). Physiologia Plantarum 83:463-468

[10] Chinmayee, M., Mahesh, B., Mary, S., Mini, I., Swapna, T. S. (2014): A comparative study of heavy metal accumulation and antioxidant responses in Jatropha curcas. - IOSR Journal of Environmental Science, Toxicology and Food Technology 8(7): 58-67.

[11] Del Rio, L. A., Corpas, F. J., Barroso, J. B. (2004): Nitric oxide and nitric oxide synthase activity in plants. - Phytochemistry 65(7): 783-792

[12] Dogan, S., Salman, U. (2007): Partial characterization of lettuce (Lactuca sativa L.) polyphenol oxidase. - Europe Food Research and Technology 226: 93-103.

[13] Esim, N., Atici, O. (2013): Nitric oxide alleviates boron toxicity by reducing oxidative damage and growth inhibition in maize seedlings (Zea mays L.). - Australian Journal of Crop Science 7(8): 1085-1092.

[14] Esmaeilzadeh, S., Rezaei, A., Najafi, S. (2015): Nitric oxide Effect on Growth and Some Physiological Parameters of Invitro Cultured Lemon Balm (Melissa officinalis L.). Journal of cell \& Tissue 6(2): 195-203

[15] Fan, X., Xie, D., Chen, J., Lu, H., Xu, Y., Ma, C., Xu, G. (2014): Over-expression of OsPTR6 in rice increased plant growth at different nitrogen supplies but decreased nitrogen use efficiency at high ammonium supply. - Plant Science 227: 1-11.

[16] Fecht-Christoffers, M. M., Braun, H. P., Lemaitre-Guillier, C., Van Dorsselaer, A., Horst, W. J. (2003): Effect of manganese toxicity on the proteome of the leaf apoplast in cowpea. - Plant Physiology 133: 1935-1946.

[17] Foyer, C. H., Descourviers, P., Kunert, K. J. (1994): Protection against oxygen radicals: an important defense mechanism studied in transgenic plants. - Plant, cell \& environment 507-523.

[18] Gajewska, E., Skłodowska, M., Słaba, M., Mazur, J. (2006): Effect of nickel on antioxidative enzyme activities, proline and chlorophyll contents in wheat shoots. Biologia Plantarum 50(4): 653-659

[19] Gomes-Júnior, R. A., Moldes, C. A., Delite, F. S., Pompeu, G. B., Gratão, P. L., Mazzafera, P., Lea, P. J., Azevedo, R. A. (2006): Antioxidant metabolism of coffee cell suspension cultures in response to cadmium. - Chemosphere 65:1330-1337.

[20] Hamill, D. E., Brewbaker, J. L. (1969): Isoenzyme polymorphism in flowering plants. IV. The peroxidise isoenzymes of maize (Zea mays L.). - Physiologia Plantarum 22: 945-58.

[21] Hasanuzzaman, M., Fujita, M. (2013): Exogenous sodium nitroprusside alleviates arsenic-induced oxidative stress in wheat (Triticum aestivum L.) seedlings by enhancing antioxidant defense and glyoxalase system. - Ecotoxicollogy 22: 584-596.

[22] Hassan, M., Mansoor, S. (2014): Oxidative stress and antioxidant defense mechanism in mung bean seedlings after lead and cadmium treatments. - Turkish Journal of Agriculture and Forestry 38: 55-61

[23] Hayat, R., Ali, S., Amara, U., Khalid, R., Ahmed, I. (2010): Soil beneficial bacteria and their rolein plant growth promotion: a review. Annals of Microbiology 60:579-598 
[24] Heath, R. L., Packer, L. (1968): Photoperoxidation in isolated chloroplasts: I. Kinetics and stoichiometry of fatty acid peroxidation. - Archives Biochemistry Biophysics 125: 189-198.

[25] Hermes, N., Lensink, R., Meesters, A.(2011): Outreach and efficiency of micro finance institutions. World Development 39(6): 938-948.

[26] Islam, X., Yang, T., Li, D., Liu, X., Jin, F. (2007): Effect of Pb toxicity on root morphology, physiology and ultrastructure in the two ecotypes of Elsholtzia argyi. Journal of Hazardous Materials 147(3): 806-816.

[27] Jhanji, S., Setia, R. C., Kaur, N., Kaur, P., Setia, N. (2012): Role of nitric oxide in cadmium-induced stress on growth, photosynthetic components and yield of Brassica napus L. - Journal of Environmental Biology 33: 1027-1032.

[28] John, R., Ahmad, P., Gadgil, K., Sharma, S. (2009): Heavy metal toxicity: Effect on plant growth, biochemical parameters and metal accumulation by Brassica juncea L. International Journal of Plant Production 3: 65-76.

[29] Johnson, F. M. (1998): The genetic effects of environmental lead. - Mutation Research/Reviews in Mutation Research 410:123-140

[30] Kumar, A., Prasad, M. N. V., Achary, M. M., Panda, B. B. (2013): Elucidation of leadinduced oxidative stress in Talinum triangulare roots by analysis of antioxidant responses and DNA damage at cellular level. - Environmental Science and Pollution Research 20: 4551-4561.

[31] Kumari, A., Sheokand, S., Swaraj, K. (2010): Nitric oxide induced alleviation of toxiceffects of short term and long term Cd stress on growth, oxidative metabolism and Cd accumulation in chickpea. - Brazilian Journal of Plant Physiology 22(4): 271-284.

[32] Laspina, N. V., Groppa, M. D., Tomaro, M. L., Benavides, M.P. (2005): Nitric oxide protects sunflower leaves against Cd-induced oxidative stress. - Plant Science 169:323330.

[33] Litehtenhaler, H.K. and A.R. Wellburn, 1983. Determination of total crotenoids and chlorophylls $\mathrm{a}$ and $\mathrm{b}$ of leaf extracts in different solvents. Biochem. Soc. Trans., 603rd Meeting Liverpool, 591-592.

[34] Malar, S., Vikram, S., Favas, P., Perumal, V. ( 2014): Lead heavy metal toxicity induced changes on growth and antioxidative enzymes level in water hyacinths [Eichhornia crassipes (Mart.)]. - Botanical Studies 55: 54-65.

[35] Mayer, M,. Harel, E. (1979): Polyphenol oxidases in plants. - Phytochemistry 18(2): 193215

[36] Mishra, S., Srivastava, S., Tripathi, R. D., Dwivedi, S., Shukla, M.K. (2008): Response of antioxidant enzymes in coontail (Ceratophyllum demersum L.) plants under cadmium stress. - Environmental Toxicology 23: 294-301.

[37] Mishra, S., Srivastava, S., Tripathi, R., Kumar, R., Seth, C., Gupta, D. (2006): Lead detoxification by coontail (Ceratophyllum demersum L.) involves induction of phytochelatins and antioxidant system in response to its accumulation. - Chemosphere. 65(6): 1027-1039.

[38] Mohan, B. S., Hosetti, B. (1997): Potential phytotoxicity of lead and cadmium to Lemna minor grown in sewage stabilization ponds. - Environmental Pollution 98:233-238

[39] Nakano, Y., Asada, K. (1981): Hydrogen peroxide scanvenged by ascorbated specific peroxidase in spinach chloroplast. - Plant Cell Physiology 22: 867-880.

[40] Nareshkumar, A., Krishnappa, B., Kirankumar, V., Kiranmai, K., Lokeshu, U., Sudhakarbabu, O., Sudhakar, C. (2014): Effect of Pb-stress on growth and mineral status of two groundnut (Arachis hypogaea L.) cultivars. - Journal of Plant Sciences 2(6): 304310.

[41] Neill, S. J., Wilson, I. D., Hancock, J. T. (2008): Nitric oxide synthesis and signaling in plants. - Plant, Cell \& Environment 31: 622-631 
[42] Nemati, H., Bostani, A., Sharafi, Y. (2013): Effects of soil lead (Pb) concentration on some qualitative and quantitative characteristics of lycopersicum esculentum. International Journal of Agronomy and Plant Production 4(3): 438-441

[43] Paczkowsk, M., Kozlowska, M., Golinski, P. (2007): Oxidative stress enzyme activity in Lemna Minor L. exposed to cadmium and lead. - Acta Biologica Cracoviensia Series Botanica 49(2): 33-37

[44] Parlak, K. C., Yilmaz, D. (2013): Ecophysiological tolerance of Lemna gibba L. exposed to cadmium. Ecotoxicol Environ Saf 91:79-85 Pilon-Smits E, Pilon M (2000) Breeding mercury-breathing plants for environmental cleanup. - Trends in Plant Science 5:235-236

[45] Patra, H. L., Kar, M., Mishre, D. (1978): Catalase activity in leaves and cotyledons during plant development and senescence. - Biochemical Pharmacology 172: 385-390

[46] Phang, F. A., Ali, M. B., Bakar, M. N., Zanzali, N. A. A., Rahman, N. F. A., Mohtar, L. E., Ghazali, N. M., Puteh, M. (2011): Engineering Elements Profile among First- and Final-Year Engineering Students in Malaysia. - IEEE EDUCON 2011, Jordan, April 2011.

[47] Pourrut, B., Shahid, M., Dumat, C., Winterton, P. Pinelli, E. (2011): Lead uptake, toxicity, and detoxification in plants. - Reviews of Environmental Contamination and Toxicology. 213: 113-136.

[48] Prasad, D. D. K., Prasad, A. R. K. ( 1987): Altered $\delta$-aminolevulinic acid metabolism by $\mathrm{Pb}$ and $\mathrm{Hg}$ in germinating seedlings of Bajra (Pennisetum typhoideum). - Journal of Plant Physiology 127: 241-249.

[49] Reddy, A. M., Kumar, S. G., Jyothsnakumari, G., Thimmanaik, S., Sudhakar, C. (2005): Lead induced changes in antioxidant metabolism of horsegram (Macrotyloma uniflorum [Lam.] Verdc.) and bengalgram (Cicer arietinum L.). - Chemosphere 60:97-104

[50] Rodriguuez-Serrano, M., Romero-puertasm, M. C., Zabaza, A., Corpas, F. J., Gomez, M., Del Rio, L. A., Sandalio, L. M. (2006): Cadmium effect on oxidative metabolism of pea (Pisum sativum L.) roots. Imaging of reactive oxygen species andnitric oxide accumulation invivo. - Plant, Cell and Environment 29(8): 1532-1544.

[51] Sadeghipour, O. (2015): Alleviation of lead toxicity by nitric oxide in cowpea (Vigna unguiculata L. Walp). - International Journal of Biosciences 6(7): 58-56

[52] Saffar, A., Najjar, M. B. Mianabadi, M. (2009): Activity of Antioxidant Enzymes in Response to Cadmium in Arabidopsis thaliana. - journal of Biological Sciences 9(1): 4450 .

[53] Sharma, P., Dubey, R. S., Pessarakli, M. (2012): Reactive oxygen species, oxidative damage, and antioxidative defense mechanism in plants under stressful conditions. Journal of Botany 217037.

[54] Sharma, P., Dubey, R. S. (2005): Pb toxicity in plants. - Brazilian Journal of Plant Physiology 17: 35-52

[55] Sheldon, A. R., Menzies, N. W. (2005): The effect of copper toxicity on the growth and root morphology of Rhodes grass (Chloris gayana Knuth.) in resin buffered solution culture. - Plant Soil 278: 341-349.

[56] Singh, H. P., Kaur, G., Batish, D. R., Kohli, R. K. (2011): Lead (Pb)-inhibited radicle emergence in Brassica campestris involves alterations in starch-metabolizing enzymes. Biological Trace Element Research 144: 1295-1301.

[57] Singh, S., Eapen, S., Souza, S. F. (2006): Cadmium accumulation and its influence on lipid peroxidation and antioxidative system in an aquatic plant, Bacopa monnieri L. Chemosphere 62(2): 233-246

[58] Tanyolac, D., Ekmekci, Y., Unalan, S. (2007): Changes in photochemical and antioxidant enzyme activities in maize (Zea mays L.) leaves exposed to excess copper. Chemosphere 67(1): 89-98.

[59] Tewari, R. K., Kumar, P., Sharma, P. N. (2006): Antioxidant responses to enhanced generation of superoxide anion radical and hydrogen peroxide in the copper-stressed mulberry plants. Planta 223:1145-53. 
[60] Ulbricht, C., Brendler, T., Gruenwald, J., Kligler, B., Keifer, D., Abrams, T. R., Woods, J., Boon, H., Kirkwood, C. D., Hackman, D. A., Basch, E., Laffrty, H. J. (2005): Lemon Balm (Melissa officinalis L.): An Evidence-Based Systematic Review by the Natural Standard Research Collaboration. - Journal of Herbal Pharmacotherapy 5(4): 71-114

[61] Verma, S., Dubey, R. S. (2003): Pb toxicity induces lipid peroxidation and alters the activities of antioxidant enzymes in growing rice plants. - Plant Science 64:645-655

[62] Wang, Y. S., Yang, Z. M. (2005): Nitric oxide reduces aluminium toxicity by preventing oxidative stress in the roots of Cassia tora L. - Plant and Cell Physiology 46: 1915-1923.

[63] Xu, Y., Sun, X., Jin, J., Zhou, H. (2010): Protective effect of nitric oxide on light-induced oxidative damage in leaves of tall fescue. - Journal of Plant Physiology 167: 512-518

[64] Zhang, Y., Han, X., Chen, X., Jin, H., Cui, X. (2009): Exogenous nitric oxide on antioxidative system and ATPase activities from tomato seedlings under copper stress. Scientia Horticulturae 123: 217-223. 